Forthcoming in Political Theory

\title{
LEGITIMACY AND ECONOMY IN DELIBERATIVE DEMOCRACY
}

JOHN S. DRYZEK

Australian National University

AUTHOR'S NOTE: Previous versions of this paper were presented to the Conference on Deliberating About Deliberative Democracy, University of Texas, Austin, 4-6 February 2000, the Social and Political Theory Program at Australian National University, and the Politics Department at Macquarie University. I am grateful for comments from Robyn Eckersley, Pablo De Greiff, Benjamin Gregg, Robert Goodin, John Parkinson, and John Uhr. 


\title{
LEGITIMACY AND ECONOMY IN DELIBERATIVE DEMOCRACY
}

\begin{abstract}
Deliberative democracy is usually presented as a polity in which legitimacy is achieved by deliberative participation on the part of those subject to a collective decision. But cast in these terms, the theory runs headlong into the long-recognized impossibility of directly involving more than a few members of any large-scale democracy in decision making. After canvassing the available solutions to this problem, an argument is made for conceptualizing deliberative democracy in terms of the contestation of discourses in the public sphere, and public opinion as the provisional outcome of this contestation as transmitted to the state. Legitimacy is then achieved to the degree collective outcomes respond to the balance of discourses in the polity, to the extent this balance is itself subject to dispersed and competent political control.
\end{abstract}




\section{THE COMPETING CLAIMS OF LEGITIMACY AND ECONOMY}

Deliberative democracy, though the dominant theme in recent democratic theory, remains on the face of it impossible - at least to the degree it is cast as an account of democratic legitimacy. Yet this is how the theory arrived in Joshua Cohen's classic formulation, and this is still the claim at the theory's core: that outcomes are legitimate to the extent they receive reflective assent through participation in authentic deliberation by all those subject to the decision in question. ${ }^{1}$ As Seyla Benhabib puts it, "legitimacy in complex democratic societies must be thought to result from the free and unconstrained deliberation of all about matters of common concern" [emphasis added]. ${ }^{2}$ The essence of deliberation is generally taken to be that claims for or against collective decisions need to be justified to those subject to these decisions in terms that, given the chance to reflect, these individuals can accept. But in real-world deliberations all or even very many of those affected do not appear to participate, thus rendering deliberative democracy vulnerable to demolition of its legitimacy claims. In the context of the supposedly exemplary case of health care rationing in Oregon, ${ }^{3}$ Ian Shapiro asks "why should we attach legitimacy at all to a deliberative process that involved very few of those whose health care priorities were actually being discussed?"4

There are ways to fudge the issue; for example, Cohen specifies only that "outcomes are democratically legitimate if and only if they could be the object of a free and reasoned agreement among equals" ${ }^{25}$ could be, rather than actually being. Casting matters in terms of the universal right, capacity, or opportunity to deliberate, rather than actual exercise of that right, capacity, or opportunity, makes deliberative democracy more plausible. So for Bernard Manin, "As political decisions are characteristically imposed on all, it seems reasonable to seek, as an essential 
condition for legitimacy, the deliberation of all or, more precisely, the right of all to participate in deliberation" ${ }^{\prime 6}$ [emphasis in original]. However, this sort of qualification places a major question mark by legitimacy. For surely the theory hangs by a slender thread if its viability depends crucially on the vast majority always choosing not to exercise the rights and capacities that are so fundamental to the theory - and whose exercise is taken by most proponents of deliberative democracy to be what makes for good citizens to begin with. Relying on mass apathy to make the theory work would return us to the dark days of the Schumpeterian, elitist models of democracy, that deliberative democrats are otherwise so keen to reject. ${ }^{7}$

The key constraint here is one of economy. Robert Dahl and many others have pointed out that meaningful participation in collective decision by anything more than a tiny minority is inconceivable in contemporary nation states (and, indeed, in most of their component units). ${ }^{8}$ The time demands on participants are simply impossible in anything beyond a very small scale political unit. As Michael Walzer puts it, "deliberation is not an activity for the demos... 100 million of them, or even 1 million or 100,000, can't plausibly "reason together.",99

Here I will briefly survey and criticize the available solutions to this problem, and propose a way to think about securing legitimacy while respecting the basic constraint of deliberative economy. ${ }^{10}$ This proposal will require close attention to, and perhaps some re-thinking about, what we actually mean by core concepts of deliberation, public opinion, legitimacy - and so by democracy. It will specify the public sphere as the most important location for deliberation, and conceptualize deliberation itself as a multifaceted interchange or contestation across discourses within the public sphere. Discursive legitimacy is then secured to the degree that collective outcomes are responsive to the balance of competing discourses in the 
public sphere, to the extent that this balance is itself subject to dispersed and competent control.

\section{DELIBERATIVE LEGITIMACY AND LARGE SCALE}

The extant solutions to the problem presented by large scale are as follows. These solutions are not mutually exclusive, and can indeed be combined.

First, deliberative democracy can be restricted to a small number of occasions when popular deliberation can occur. John Rawls believes that extended deliberation is appropriate only to matters concerning the constitution, and legislation inasmuch as "basic justice" (equality of opportunity and material distribution) is at issue. ${ }^{11}$ Yet the problem of scale remains even on such special occasions. Take, for example, the recent (1999) referendum in Australia on whether or not to ditch the British monarch in favor of a (particular model of) a republic. The failure of the republican proposal in the referendum compared to the overwhelming success of the model in a setting provided by a deliberative opinion poll (of which more shortly) suggests that this occasion, at least, was a deliberative failure at the national level - even in a population of (only) 19 million. The sheer impossibility of involving more than a handful of members of the population in deliberation remains overwhelming. As we shall see shortly, Rawls himself sees no problem in restricting deliberation to a wellqualified handful.

The number of occasions for society-wide deliberation is restricted still further by Bruce Ackerman, who argues that the political history of the United States has seen just three such occasions: the constitutional founding, the Civil War amendments

to the Constitution, and the New Deal. ${ }^{12}$ But even on these rare great crises of the 
state, it certainly was not a matter of all the people deliberating, however much deliberative circles may have been widened. And even if these three occasions were the only three rightful candidates, it would seem odd to rest an account of democratic legitimacy on events that most citizens may well go through their lives without ever seeing.

The second solution, perhaps more straightforward than the first, is somehow to restrict the number of people involved in deliberation, making sure that the individuals who do participate be in some way representative of those who do not. There are two main ways of securing representativeness: by popular election, and by random selection. The former is of course acceptable to those theorists who see deliberation as an aspect of, rather than substitute for, conventional sorts of representative democracy. ${ }^{13}$ But such an easy assimilation to representative democracy cannot straightforwardly deliver on the legitimacy requirements of deliberative democrats such as Cohen, Benhabib, and Manin. For to do so, election campaigns themselves would have potentially to involve the deliberation of all. So the problem of scale re-appears, only this time in a slightly different location, and a legitimacy claim cannot be established at one remove simply by appeal to the electoral process.

Deliberative democracy's legitimation problems are compounded here to the degree elections themselves are not exactly deliberative affairs even for those who do participate in them - deliberation often has to be subordinated to strategy in the interests of winning. One way to avoid this anti-deliberative aspect of election campaigns is to select deliberators by lot instead of election - as is done for James Fishkin's deliberative opinion polls, for citizen juries, for Dahl's proposed "minipopulus", and for John Burnheim's proposed "demarchy". ${ }^{14}$ Such forums are 
usually constituted on an issue-specific basis, and their role but advisory - though there is no reason why they could not be decisive, or indeed act as general-purpose legislatures.

Random sampling of the relevant population followed by deliberation gives a simulation of what the population as a whole would decide if everyone were allowed to deliberate. This simulation may not hold if the deliberation so organized fails to capture the differentiated character of political interchange - i.e, the fact that in reality people encounter each other largely within or across groups, as opposed to an undifferentiated forum. (Sanders suggests that this means deliberative polls misrepresent group processes. ${ }^{15}$ ) However, even if we grant the simulation claim, it does not entirely solve the legitimation problem, because decisions still have to be justified to those who did not participate. Still, such justification ought to be easier than for elections - provided that enough of the population could come to understand the logic of random sampling. The problem is that it is not easy to see how the outcome of a deliberative poll could be justified without somehow involving the population at large in deliberation. Simply televising and publicizing the poll is insufficient - as perhaps the Australian example indicates, where the majority of those voting in the referendum chose the opposite of the deliberators' recommendation. Another problem that may arise is that deliberative polls and citizen juries normally require that well-defined boundaries can be drawn around issues. Sometimes they can (for example, when it comes to a constitutional question such as the Australian transition from monarchy to presidency), but for some issues there will be a variety of important interactions across issues (for example, concerning issues of free trade and capital mobility, which have major ramifications for environmental affairs and social justice). 
Non-democratic ways of restricting the number of participants in deliberation also merit attention. Consider in this light how Rawls specifies deliberative practice in terms of the exercise of public reason, a standard for the substantive content of arguments, which have to be framed in terms that can be accepted by all, thus excluding self-interest and partial perspectives. ${ }^{16}$ Public reason for Rawls is singular and universal: its terms are identical for all, and all individuals who exercise it will reach the same conclusions. Public reason is defined by a body of principles that people must accept before they enter a political setting, not what they will be prompted to discover after they have entered the public arena. ${ }^{17}$ Thus any reflective individual can reach the correct conclusions, and so all that is really needed is one individual to deliberate about its content - an obvious solution to the problem presented by large scale. If some people are better able to reflect than others, perhaps political philosophers and legal theorists, then they should be the ones to whom society entrusts public reason. This perhaps helps to explain Rawls's own enthusiasm for the U.S. Supreme Court. ${ }^{18}$

Restriction of numbers of deliberators along Rawlsian lines means that public reason does not have to be tested in political interaction, and there is in fact no reason why it should be so tested. Political venues for deliberation, be they courts or legislatures (Rawls's favorite places), function so as to provide opportunity for expression; in this light, there is nothing interactive about them that induces proper public reason. Rawls is a deliberative theorist, but not a deliberative democrat, his own self-description notwithstanding. ${ }^{19}$ The Supreme Court is a deliberative institution, but not really an interactive one, and most certainly not a democratic one. The problem of legitimation arises still more acutely for such non-democratic deliberation than for deliberation on the part of representatives. Institutions such as 
the Supreme Court can only contribute to legitimacy to the extent that the public accepts that public reason is indeed singular, and that professional experts in the exercise of public reason do indeed know best.

A third solution to the challenge of deliberative economy is advanced by Robert Goodin, who wants those who do participate in proceedings to call to mind the interests of those who do not participate. ${ }^{20}$ Thus those who cannot or choose not to participate still have their interests entered into deliberation - but it is "internalindividual" deliberation as cogitation, within the minds of those who do participate. This sort of deliberation resembles Rawlsian public reason, at least inasmuch as deliberation is seen mainly as a matter of personal cogitation in light of public concerns, not as a social or interactive process.

This kind of partial substitution of internal-individual deliberation for real interaction is advocated in a somewhat different context by Robyn Eckersley, whose concern is with extending deliberation to a "community of the affected" that encompasses future generations and the nonhuman world. ${ }^{21}$ Given that there is no conceivable way that future persons or nonhumans can give literal voice to their concerns, they can only be made virtually present in deliberations. ${ }^{22}$ One could also imagine this sort of presence being used in connection with the extension of deliberative democracy across national boundaries as proposed by Thompson, who wants participants in decision making in state structures to be induced to internalize the interests of those residing in other states. (Thompson himself does not advocate internal-individual deliberation, but rather representative devices such as a "tribune for non-citizens".23)

Goodin's solution in fact presupposes that we have already restricted the number of deliberators. Given the criticisms he levels at selection by lot, in contrast 
with the free passage he grants more conventional representation, he appears to have the latter in mind. But in specifying a key role for "deliberation within", Goodin intensifies the legitimation problem for elected representatives. For he is asking members of the broader public to take it on trust that the deliberators really are calling to mind and internalizing broader sets of interests. At least in the case of the Supreme Court a public record (or at least rationalization) of internal-individual deliberation is supplied, against which members of the public could, if so inclined, check the justices' version of public reason against their own. Goodin hints at no such check.

Having surveyed three available solutions to the problem of deliberative economy, my own view is that it is deliberation on the part of representatives selected by lot that presents the fewest problems for democratic legitimacy. But even here, substantial legitimation problems remain when it comes to persuading those who did not participate that their reflective opinions would in fact be the same as those who did deliberate, despite likely surface evidence to the contrary. Reacting to the results of the recent Australian deliberative poll on monarchy vs. republic, one of the leaders of the "real republic" faction urging a "no" vote to the model of the republic on offer dismissed the deliberative poll as an exercise in "push-polling". ${ }^{24}$ There are also issues of practicality, if we try to assemble such bodies on more than a few issues.

A fourth solution can be discerned in Jürgen Habermas's "two track" account of deliberation in the public sphere and in the legislature, designed with contemporary complex and plural societies in mind ${ }^{25}$ (unlike his earlier exemplar, the more direct and personal communication that defined the far simpler early bourgeois public sphere $\left.{ }^{26}\right)$. Legitimacy is secured by public acceptance of the procedures through which law-making achieves responsiveness to public opinion as formed in a broader public sphere. Public opinion is converted into communicative power as a result of 
the electoral process, then into administrative power via law making. The problem of deliberative economy is solved because only a small number of legislators needs to deliberate about the content of law.

In terms of the need to secure legitimacy while respecting the constraint of economy, the two-track model is inadequate for a number of reasons. First, it is a bit ambiguous about extra-constitutional agents of influence. There are times when Habermas remembers the myriad ways public opinion can affect state action without necessary reference to elections, ${ }^{27}$ other times when elections are central. ${ }^{28}$ But he ignores the fact that public opinion can affect state action without reference to the legislature. For administration itself is political, sometimes even deliberative and responsive to public opinion, not necessarily the mechanical servant of the legislature. Later I will argue that such extra-constitutional influences can be drawn into the service of legitimacy. Second, Habermas's stress on elections plays into the hands of social choice theorists such as William Riker and his followers who argue that the popular will has no content independent of the voting system used to measure it. ${ }^{29}$ But the most serious flaw in the model is its unremitting proceduralism: Habermas gives no way to determine what the content of public opinion actually is on an issue. As I have noted, legitimacy for Habermas is secured by public acceptance of procedural responsiveness, not by the actual responsiveness of pieces of legislation to the substance of public opinion on an issue. Thus it remains unclear what exactly it is that particular deliberations in the legislature are supposed to be responsive to (especially once we recognize that elections cannot easily answer this question). If the answer to this question is opaque to observers, it will be equally opaque to legislators, and to actors within the public sphere. I will attempt to remedy these deficiencies. ${ }^{30}$ 


\section{DELIBERATION AS THE CONTESTATION OF DISCOURSES}

Rather than wrestle further with the issue of legitimation in the context of these ultimately ineffective responses to the challenge of deliberative economy, let me suggest that the best way forward here involves detaching the idea of legitimacy from a head count of (real or imaginary) reflectively consenting individuals. Such a move might on the face of it seem to involve rejection of both the very idea of legitimation and of deliberative democracy itself. But on closer inspection all it will prove to require is thinking in a slightly different direction about the entities that populate the political world - not all of which need to be reduced to individuals. My approach builds on a conception of discursive democracy that emphasizes the contestation of discourses in the public sphere. ${ }^{31}$

Deliberative democrats influenced by Habermas have long emphasized the public sphere as perhaps the most important location for deliberative politics. ${ }^{32}$ Habermas himself now speaks of dispersed "subjectless communication" that generates public opinion. ${ }^{33}$ Similarly, Benhabib speaks of an "anonymous public conversation" in "interlocking and overlapping networks and associations of deliberation, contestation, and argumentation". ${ }^{34}$

In order to give more substance to the idea of diffuse deliberation in the public sphere than the rather imprecise and intangible formulations of Habermas and Benhabib, I suggest we recognize that the public sphere is at any time home to constellations of discourses. A discourse may be defined in un-Habermasian terms as a shared way of comprehending the world embedded in language. In this sense, a discourse will always feature particular assumptions, judgments, contentions, dispositions, and capabilities. These common terms mean that adherents of a given 
discourse will be able to recognize and process sensory inputs into coherent stories or accounts, which in turn can be shared in intersubjectively meaningful fashion. Accordingly, any discourse will have at its center a storyline, which may involve opinions about both facts and values.

Consider, for example, the area of criminal justice, which is currently home to at least three competing discourses. One treats crime as a matter of rational calculation on the part of potential lawbreakers; the storyline is one of fully competent individuals weighing in their minds the expected subjective benefit of the crime against the probability of being caught and the severity of the punishment. A second emphasizes instead the circumstances of poverty and deprivation that cause individuals in desperation to commit criminal acts. A third emphasizes the psychopathology of criminals. Each discourse has at its heart a different model of the (criminal) human being, his or her capacity for autonomous agency, and likely motivations. Each is also entwined with values about what constitutes normal, criminal and deviant behavior; and about what kind of punishment or treatment is desirable. Each can be both backed or undermined by empirical studies that are unlikely to convince adherents of different discourses. Each is entwined with ideological positions taken by politicians. The content of public policy at any time and place depends crucially on the relative weight of these discourses.

Other contemporary examples of particularly powerful discourses would include market liberalism - arguably the dominant policy discourse of our time; sustainable development, which since the mid-1980s has dominated global environmental affairs; and various feminisms.

Now, followers of Michel Foucault often treat discourses as power/knowledge formations that condition - to the extent of imprisoning - human subjects. If so, then, 
it is hard to be a Foucauldian and a deliberative democrat, because deliberation across discourses is hard to imagine. Still, I think it is useful to begin with a very loosely Foucauldian conception of discourses while recognizing that reflective choice across discourses is indeed possible (and this is where deliberation can come in). Foucault leaned closer to acceptance of this possibility toward the end of his life. Pierre Bourdieu speaks of a "discursive field" that actors, who may be in opposition to one another, can occupy. ${ }^{35}$ The contours of this field limit the positions that actors can take, but the structure of the field is itself a result of their actions, interactions, and contestations. And though they do not use the "discourse" terminology, the notion of a reflexive modernity as advanced by Ulrich Beck and Anthony Giddens suggests that choices across discourses become increasingly possible and likely with the "detraditionalization" of society. ${ }^{36}$ The traditions that can be called into question include those that once took economic growth and technological change as inevitable and benign, as well as older traditions of deference and religious authority. Indeed, for Beck the possibility of such choices becomes the defining feature of modernity proper (as opposed to the semi-modernity of industrial society). Which ought to augur well for the prospects for deliberative democracy.

Elswhere I argue for a conception of discursive democracy in terms of the contestation of discourses in the public sphere on the grounds that it constitutes the only effective reply to two sets of critics of deliberation. ${ }^{37}$ The first set is composed of social choice theorists inspired by Riker, who argue that the very conditions of structurelessness favored by deliberative democrats are exactly the conditions most conducive to arbitrariness, instability, and so manipulation in collective choice. ${ }^{38}$ This critique has force so long as deliberation is a prelude to aggregation of opinion, usually by voting. However, if we re-conceptualize public opinion in terms of the 
provisional outcome of the contestation of discourses as transmitted to the state, the Riker-inspired critique dissolves. Such transmission from the public sphere can come about through a number of means. These include the deployment of rhetoric, through alteration of the terms of political discourse in ways that come to change the understandings of state actors (as Habermas puts it, "Communicative power is exercised in the manner of a siege. It influences the premises of judgment and decision making in the political system without intending to conquer the system itself." $\left.{ }^{39}\right)$, through creating worries about political instability, and sometimes even through arguments being heard by public officials. In short, there are many nonelectoral and non-voting avenues of influence that by-pass the social choice critique (in this light, in is hard to see why Habermas becomes so insistent in stressing elections as the main channel of influence from the public sphere to the state ${ }^{40}$ ).

Now, this re-specification of discursive democracy and public opinion is not the only way to reply to the social choice critique (for example, David Miller argues that social choice theory highlights some problems which deliberation can solve by disaggregating the dimensions of collective choice ${ }^{41}$ ). However, it has the benefit of also responding to a set of critics who arrive from precisely the opposite direction: difference democrats who charge deliberative democrats with perpetuating an exclusive gentlemen's club. ${ }^{42}$ Where social choice theorists fear unmanageable diversity, difference democrats see stifling uniformity, under which deliberation is dominated by well-educated white males well-versed in the niceties of rational argument. In this light, seemingly neutral deliberative procedures are systematically biased precisely because they traffic in unitary notions of public reason.

Taking difference seriously means attending to different identities and the different kinds of communication that accompany them, refusing to erase them in the 
name of a unitary public reason. This does not mean that "anything goes" in terms of the kinds of communication that deliberative democrats ought to welcome, as well as argument. Many forms of communication can be welcomed (including gossip, jokes, performances) provided they are (a) capable of inducing reflection, (b) noncoercive, and (c) capable of connecting the particular experience of an individual, group, or category with some more general principle. ${ }^{43}$

Identity differences should not be allowed to warrant a relativism in which deliberation is impossible and identities are only asserted dogmatically (as feared, for example, by William Connolly ${ }^{44}$ ). Rather, we should remember that any identity is tightly bound up with a discourse. The possibility for deliberation is retained to the extent that reflective interchange is possible across the boundaries of different discourses - which, I would argue once again, is the defining feature of a reflexive modernity.

Deliberation as the contestation of discourses in the public sphere remains faithful to the core idea of deliberative democracy, which, as I noted at the outset, is that claims on behalf of or opposing collective decisions require justification to those subject to these decisions in terms that, on reflection, these individuals can accept. At the same time, conceiving of deliberation as the contestation of discourses enables effective response to the criticisms levelled by social choice theorists and difference democrats. Let me now try to make the connection to legitimation in a way that respects the constraint of deliberative economy. 


\section{DISCURSIVE LEGITIMACY}

Let me define discursive legitimacy as being achieved when a collective decision is consistent with the constellation of discourses present in the public sphere, in the degree to which this constellation is subject to the reflective control of competent actors. This conception accompanies a definition of public opinion as the provisional outcome of the contestation of discourses in the public sphere as transmitted to the state (or transnational authority).

Clearly it is impossible for any decision fully to meet the claims of all competing discourses. That would only be possible if one could envisage consensus in collective choice, defined as agreement on both a course of action and the reasons for it. In a world of competing discourses, one can imagine such consensus only if the discourses were themselves either merged or dissolved - a prospect that is both unlikely and undesirable, inasmuch as it would erase the differences that make deliberation both possible and necessary. The ideal of consensus has long been rejected by most deliberative democrats, even those sympathetic to the Habermasian tradition where consensus once played a central role in the counterfactual standard of the ideal speech situation, ${ }^{45}$ though their opponents have not always noticed. Workable agreements (or what Cass Sunstein calls "incompletely theorized agreements") in which assent can be secured for courses of action for different

reasons are far more plausible. ${ }^{46}$ Such agreements will vary in their degree of resonance with the prevailing constellation of discourses. More resonance means more discursive legitimacy.

How can this degree of resonance be ascertained? This issue can be unpacked into three questions. First, what discourses exist? Second, what is their relative 
weight? Third, are collective decisions consistent with this relative weight? The first question can be answered using empirical discourse analysis; qualitative and quantitative methods are available. ${ }^{47}$ The second question is trickier. One might, for example, administer a sample survey with items informed by the results of discourse analysis ${ }^{48}$ but that would indicate only the percentage of the citizenry evidencing support for a discourse, not the depth or political significance of that support. The third question is easy once the first two have been answered, requiring only an examination of the content of public policy and other collective outcomes for consistency with the relative weight of discourses. So, for example, Maarten Hajer shows that environmental policy in the Netherlands features a disjuncture between a "Chamber of Concern" dominated by apocalyptic discourse accepting environmental crisis and a "Chamber of Regulation" where economic feasibility determines the content of policy. ${ }^{49}$

The availability of such procedures shows that tangible and measurable phenomena are at issue. The problem is that as presented they substitute social science for democratic process, though in this respect they are no worse than ordinary opinion surveys, and can be seen as just external checks on the operation of democracy. There is no reason why political actors cannot make corresponding tacit judgments. Gross violations of consistency at least may be easy to detect (for example, the imposition of a Poll Tax by Margaret Thatcher's government in the United Kingdom in 1990 that met with massive public protest). But one might say the same about elections as highlighted in more conventional models of democracy. Elections can register the massive and obvious in public opinion, but cannot otherwise represent the popular will (again, as social choice theorists make clear). 
Any possibilities for reasoned agreement resonating with the prevailing constellation of discourses notwithstanding, there will inevitably be times when particular discourses lose out in the contest for influence. Those attuned to an individualistic ontology would probably ask why partisans of losing discourses should accept outcomes. ${ }^{50}$ For surely, these individualists would say, we still have to ask this question, because discourses as supra-individual entities are not in a position to confer or withdraw legitimacy, because they lack agency. The resonance of discourses with collective outcomes is something that can be discerned by an observer, but not felt by discourses - because discourses cannot feel.

It is important here to resist reducing discourses to an individualistic ontology in such fashion, because though discourses do not possess agency, they do possess the capacity to underwrite or destabilize collective outcomes - which, from the point of view of legitimacy, is the most important aspect of agency to begin with. ${ }^{51}$ This resistance to reductionism does not mean that reflecting individuals need to be purged from the account. It is simply to imply that these individuals are not required to pass competent judgment on every collective outcome to which they are subject (this would of course run headlong into the economy constraint). They can, however, still engage the contestation of discourses as they see fit.

Indeed, it is important that such engagement be possible. For particular discourses might of course be slaves to tradition or religion; or subject to manipulation by spin doctors, advertisers, and propagandists. Such is the very antithesis of deliberative democracy. Crucially, then, the constellation of discourses must itself be open to dispersed and communicatively competent popular control which returns us to the idea of a reflexive modernity. (I will return to ways such control can be exercised shortly.) 
Having established what discursive legitimacy means, all that now remains to be shown is how it meets the constraint of deliberative economy. To re-state the challenge: deliberative democracy requires that for a collective decision to be legitimate, it must be subject to reflective acceptance of those subject to it, who should be able to participate in deliberation concerning the production of the decision. But reflective acceptance must be attained in a way that does not impose impossible burdens on the deliberative capacities of individuals or polity. As I have noted, the most plausible existing approaches respond to the challenge by somehow restricting the number of participants.

The approach I propose here solves the problem because the number of participants in deliberation is indeterminate. That is, it does not require any exclusions - not even exclusions based on not being selected at random for a citizen's jury, or not being elected to parliament, or on apathy, or on a choice not to exercise deliberative citizenship rights. At any given time, the contestation of discourses can be engaged by the many or the few, or indeed by none. Typically that number will fluctuate widely over time for any given issue area; think, for example, of the upsurges in environmental concern in most developed countries around 1970 and again around 1990. Such upsurges might lead to dramatic shifts in the prevailing balance of discourses - which might then remain settled for a while, and receive less public attention. Who can engage such contestation? Pretty much everybody; for the contestation of discourses overlaps with cultural change. Think, for example, of the life and times of feminism over the past three decades in its contest with patriarchy, or environmentalism's rise in a (continuing) contest with industrialism. These discursive advances cannot just be measured in terms of legislation or policy decisions; but also in everyday practice, in challenges made and resisted in households, in workplaces, in 
classrooms, and elsewhere (relatedly, Jane Mansbridge speaks of the role of "everyday talk" in the "deliberative system",52).

This indeterminacy in numbers of participants in the contestation of discourses solves the seeming incompatible demands of deliberative economy and the need for collective decisions to secure actual popular reflective acceptance. A Schumpeterian might argue here that all that has been done is to substitute packages in the form of discourses for individuals - paralleling the way Schumpeterians substitute the platforms of competing party elites for the will of the people. But there is a crucial difference, because Schumpeterians require that ordinary people do no more than vote, and then sleep between elections. In contrast, discursive contestation can accept, even welcome, the participation of the many at any time. Moreover, party platforms are crafted by elites, whereas discourses can be made and re-made by anybody.

My argument does not imply that the deliberative democrat can sit back and accept society's prevailing constellation of discourses, their changes over time, and the many ways in which these discourses can pervade policy making. There are still insistently critical roles to be played. First, deliberative democrats can expose occasions where state imperatives (related, for example, to the need to maintain the confidence of financial markets) override the constellation of discourses in determining the content of public policy. ${ }^{53}$ Second, they can expose the degree to which popular discourses themselves are ideological (in the pejorative sense of specifying false necessities, perhaps even the necessity of always having to please financial markets; discourses are inescapably ideological in a more neutral sense of "ideology"). Third, they can criticize the degree to which the contestation of discourses is manipulated by strategy and power and not subject to reflexive control. 


\section{NETWORKS AND DEMOCRATIC CONTROL}

Democratic theorists can also think about ways in which that contestation can be subjected to more in the way of dispersed and competent democratic control. Let me illustrate with just one such way.

The role that networks can play in the public sphere has recently been investigated by David Schlosberg in a study of the U.S. environmental justice

movement. ${ }^{54}$ A network begins from the bottom up, and is especially interesting from the point of view of the contestation of discourses when it brings together actors with quite different backgrounds. Such is certainly the case for the U.S. environmental justice movement. This began in 1978 in Love Canal, where working-class whites were upset at the toxic chemicals found buried beneath their homes - one of whom, Lois Gibbs, became a key figure in the development of the network. The movement grew to encompass groups from very different racial, ethnic, and class backgrounds, and very different kinds of experiences - though of course they share the experience of exposure and resistance to environmental hazards. Networks of this sort can also extend across national boundaries - as is the case for international networks concerned with, for example, biopiracy, pollution from oil refineries, or landmines. With the possible exception of an informational clearing house (the most famous of which is perhaps the Citizen's Clearinghouse for Hazardous Waste, which in 1997 changed its name to the Center for Health, Environment and Justice), a network does not have any central organization, still less an organizational hierarchy.

From the point of view of the democratic contestation of discourses in the public sphere, networks are especially interesting because, to the degree they engage truly diverse participants, networks just have to work according to principles of 
equality, openness, respect, and reciprocity - the standard deliberative virtues. These principles do not just happen to describe particular networks; they are necessary for the network form. There is no centralized hierarchy or leadership promulgating goals, norms, and strategies to bring diverse participants into line. The norms that a network develops can however sometimes be formalized as constitutive principles. ${ }^{55}$

Networks do engage in discursive contests, but the positions they take grow out of the experiences of network participants. For example, the very concept of environmental justice emerges from what began as a collection of local anti-toxics struggles. The idea that environmental risks are systematically maldistributed across lines of race, ethnicity, and class came later, the product of a variety of local but eventually interconnected experiences. The discourse of environmental justice could then contest, engage, and change other kinds of environmentalism - as well as join them in a larger contest against the discourse of industrialism.

To return to the issue of legitimacy, environmental justice joins other discourses in pressing claims on collective decisions. It would be an oversimplification to say that a collective decision in environmental affairs is legitimate only to the degree of its consistency with the discourse of environmental justice. As I said earlier, no decision can ever fully meet the claims of all competing discourses, for consensus is in reality neither possible nor desirable. Workable agreements that can secure assent for different reasons are more plausible. Discursive legitimacy is achieved to the extent of the resonance of such an agreement with the prevailing constellation of discourses in the degree to which this constellation is subject to dispersed and competent control - to which networks in the public sphere can contribute. 
What conditions are conducive to this sort of popular control? The difficulty here is that a public sphere is not a formal institution, and so cannot be designed. In Habermas's terms it is "a "wild" complex that resists organization as a whole." Networks, in particular, can only arise from the bottom up if they are to have the discursive qualities I have described. Yet public spheres take shape in relation to other authority structures that can be designed, or at least reconstituted at the margins. Foremost among these is the state. The discursive vitality of the public sphere is facilitated by a state that is passively exclusive in the form of interest representation it allows. ${ }^{57}$ The Federal Republic of Germany from the 1950s to the 1980 s exemplifies this sort of state, featuring as it did tripartite corporatism (government, business, and labor) and a legalistic, unitary conception of the public interest in administration and law. Social movements flourished precisely because they were excluded from but not undermined by the state. Actively exclusive states (such as Thatcher's Britain in the 1980s) undermine the conditions of association in public spheres. Actively inclusive states (for example, Norway) have no public sphere with any distance from the state. And passively inclusive states (for example, the United States) convert public spheres into interest groups (though, as the environmental justice example suggests, such conversion can be resisted, at least temporarily).

\section{CONCLUSION}

Democracy does not have to be a matter of counting heads - even deliberating heads. Nor does it have to be confined to the formal institutions of state, or the constitutional surface of political life. Accepting such confinement means accepting a needlessly thin conception of democracy, and a needlessly tenuous account of 
deliberative legitimacy. I have argued here that legitimacy can be sought instead in the resonance of collective decisions with public opinion, defined in terms of the provisional outcome of the contestation of discourses in the public sphere as transmitted to the state or other authorities (such as transnational ones). Moreover, legitimacy can be achieved in a way that meets the basic constraint of deliberative economy. But we should speak of discursive legitimacy only to the extent that contestation can be engaged by a broad variety of competent actors. Unlike other approaches to deliberative legitimacy, in the end it does not matter whether at any one time the number of such actors is large or small. 
NOTES

1 Joshua Cohen, "Deliberation and Democratic Legitimacy," in The Good Polity: Normative Analysis of the State, eds. Alan Hamlin and Philip Pettit (Oxford: Basil Blackwell, 1989): 17-34. See also Bernard Manin, “On Legitimacy and Political Deliberation," Political Theory 15 (1987): 338-68.

${ }^{2}$ Seyla Benhabib, “Toward a Deliberative Model of Democratic Legitimacy," in Democracy and Difference: Contesting the Boundaries of the Political, ed. Seyla Benhabib (Princeton: Princeton University Press, 1996): 67-94 at 68.

${ }^{3}$ See, for example, Amy Gutmann and Dennis Thompson, Democracy and Disagreement (Cambridge, MA: Harvard University Press, 1996), 144.

${ }^{4}$ Ian Shapiro, "Enough of Deliberation: Politics is About Interest and Power," in Deliberative Politics: Essays on Democracy and Disagreement, ed. Stephen Macedo (New York: Oxford University Press, 1999): 28-38 at 33.

${ }^{5}$ Cohen, "Deliberation and Democratic Legitimacy," 22.

${ }^{6}$ Manin, “On Legitimacy and Political Deliberation,” 352.

${ }^{7}$ Defenders of the approach to deliberative legitimacy taken by authors such as Benhabib, Cohen, and Manin might say they are simply presenting a counterfactual ideal through reference to which various practical proposals can be evaluated. But the ideal is so far from any plausible real-world proposals that it has little ability to sort them.

${ }^{8}$ Robert A. Dahl, After the Revolution? (New Haven, CT: Yale University Press, 1970).

${ }^{9}$ Michael Walzer, "Deliberation, and What Else?" in Deliberative Politics: Essays on Democracy and Disagreement, ed. Stephen Macedo (New York: Oxford University Press. 1999): 58-69 at 68. 
${ }^{10}$ Not to be confused with Gutmann and Thompson's proposed "economy of moral disagreement", which refers to the idea that deliberators who disagree on fundamental matters should nevertheless seek to identify points where they can agree. See Gutmann and Thompson, Democracy and Disagreement.

${ }^{11}$ John Rawls, Political Liberalism (New York: Columbia University Press, 1993).

${ }^{12}$ Bruce Ackerman, We the People I: Foundations (Cambridge, MA: Harvard University Press, 1991).

${ }^{13}$ For example, Joseph M. Bessette, The Mild Voice of Reason: Deliberative Democracy and American National Government (Chicago: University of Chicago Press, 1994); Cass Sunstein, "Deliberation, Democracy, Disgareement," in Justice and Democracy: Cross-Cultural Perspectives, eds. Ron Bontekoe and Marieta Stepaniants (Honolulu, HI: University of Hawai'i Press, 1997): 93-117 at 94.

${ }^{14}$ James Fishkin, Democracy and Deliberation: New Directions for Democratic Reforms (New Haven, CT: Yale University Press, 1991); James Fishkin, The Voice of the People: Public Opinion and Democracy (New Haven, CT: Yale University Press, 1995); Robert A. Dahl, Controlling Nuclear Weapons (Syracuse, NY: Syracuse University Press, 1985); John Burnheim, Is Democracy Possible? (Cambridge: Polity, 1985).

${ }^{15}$ Lynn Sanders, "Poll Envy: An Assessment of Deliberative Polling," The Good Society 9 (1) (1999): 9-14.

${ }^{16}$ Rawls, Political Liberalism; John Rawls, "The Idea of Public Reason Revisited," University of Chicago Law Review 94 (1997): 765-807.

${ }^{17}$ See Benhabib, "Toward a Deliberative Model," 75.

${ }^{18}$ Rawls, Political Liberalism, 231.

${ }^{19}$ Rawls. "The Idea of Public Reason.” 771-2. 
${ }^{20}$ Robert E. Goodin, “Democratic Deliberation Within,” Philosophy and Public Affairs 29 (2000): 81-109.

${ }^{21}$ Robyn Eckersley, "Deliberative Democracy, Ecological Risk, and 'Communitiesof-Fate'," in Democratic Innovation: Deliberation, Association, and Representation, ed. Michael Saward (London: Routledge, 2000).

${ }^{22}$ For an argument that communications from nonhuman entities can be received by deliberators, see John S. Dryzek, "Political and Ecological Communication," Environmental Politics 4 (1995): 13-30.

${ }^{23}$ Dennis Thompson, "Democratic Theory and Global Society," Journal of Political Philosophy 7 (1999): 111-25 at 122.

${ }^{24}$ Phil Cleary, quoted in The Age, Melbourne, 25 October 1999, p. 1. Push-polling is a marketing tactic where interviewees are asked leading questions and given biased information in order to induce them to buy a product - or support a position or candidate.

${ }^{25}$ Jürgen Habermas, Between Facts and Norms: Contributions to a Discourse Theory of Law and Democracy (Cambridge, MA: MIT Press, 1996).

${ }^{26}$ Jürgen Habermas, Structural Transformation of the Public Sphere: An Inquiry into a Category of Bourgeois Society (Cambridge, MA: MIT Press, 1989).

${ }^{27}$ For example, Habermas, Between Facts and Norms, 185, 308.

${ }^{28}$ See especially Jürgen Habermas, "Three Normative Models of Democracy," in Democracy and Difference: Contesting the Boundaries of the Political, ed. Seyla Benhabib (Princeton: Princeton University Press, 1996): 21-30 at 28. See also Habermas, Between Facts and Norms, 368, 381. 
${ }^{29}$ William H. Riker, Liberalism Against Populism: A Confrontation Between the Theory of Democracy and the Theory of Social Choice (San Francisco: W.H. Freeman, 1982).

${ }^{30}$ Other problems arise in applying the model to the real world that is supposedly its justification. Habermas recognizes, but does not develop an adequate response to, some serious constraints upon law making and policy making that do not emanate from, and can override, public opinion. These anti-democratic constraints include the pervasive political influence of money and corporate power, and the policy imperatives dictated by the need to please financial markets and avoid disinvestment or capital flight. At a potentially high cost to his theory, at one point he suggests that the public sphere is more vulnerable to such distortions than is the legislature; see Between Facts and Norms, 307-8.

${ }^{31}$ John S. Dryzek, Deliberative Democracy and Beyond: Liberals, Critics, Contestations (Oxford: Oxford University Press, 2000). The terms "deliberative democracy" and "discursive democracy" are now used interchangeably, and "deliberative democracy" more often. However, I believe it useful to recover the idea of discursive democracy as a critical sub-category of deliberative democracy. When it comes to contestation, Fraser too speaks of contestation in the public sphere, though engaged by publics rather than discourses. Specifically, contestation for Fraser characterizes the orientation of "subaltern counterpublics" to dominant power structures. She treats contestation as an alternative to deliberation, rather than a category of deliberation. See Nancy Fraser, "Rethinking the Public Sphere: A Contribution to the Critique of Actually Existing Democracy," in Habermas and the Public Sphere, ed. Craig Calhoun (Cambridge, MA: MIT Press, 1992): 109-42. 
${ }^{32}$ For example, Benhabib, "Toward a Model of Democratic Legitimacy"; James

Bohman, Public Deliberation: Pluralism, Complexity, and Democracy (Cambridge,

MA: MIT Press, 1996); John S. Dryzek, Discursive Democracy: Politics, Policy, and

Political Science (New York: Cambridge University Press, 1990).

${ }^{33}$ Habermas, Between Facts and Norms, 486.

${ }^{34}$ Benhabib, "Toward a Model of Democratic Legitimacy," 74.

${ }^{35}$ Pierre Bourdieu, The Field of Cultural Production (Cambridge: Polity, 1993).

${ }^{36}$ See, for example, Ulrich Beck, Anthony Giddens, and Scott Lash, Reflexive

Modernization: Politics, Tradition and Aesthetics in the Modern Social Order

(Cambridge: Polity, 1994).

${ }^{37}$ Dryzek, Deliberative Democracy and Beyond.

${ }^{38}$ For example, David van Mill, “The Possibility of Rational Outcomes from

Democratic Discourse and Procedures," Journal of Politics 58 (1996): 734-52.

${ }^{39}$ Habermas, Between Facts and Norms, p. 486.

${ }^{40}$ Habermas, Between Facts and Norms; Habermas, "Three Normative Models."

${ }^{41}$ David Miller, "Deliberative Democracy and Social Choice," Political Studies 40 (special issue): 54-67.

${ }^{42}$ For example, Iris Marion Young, "Communication and the Other: Beyond Deliberative Democracy," in Democracy and Difference: Contesting the Boundaries of the Political, ed. Seyla Benhabib (Princeton: Princeton University Press, 1996): 120-35; Iris Marion Young, “Inclusive Political Communication: Greeting, Rhetoric and Storytelling in the Context of Political Argument," paper presented at the Annual Meeting of the American Political Science Association, Boston, MA, 1998; Lynn Sanders, “Against Deliberation,” Political Theory 25 (1997): 347-76. Similar 
concerns were raised by Jane Mansbridge, "Feminism and Democracy, "American Prospect 1 (1990).

${ }^{43}$ Dryzek, Deliberative Democracy and Beyond, 68. On applying the third of these tests to testimony, see also David Miller, "Is Deliberative Democracy Unfair to Disadvantaged Minorities?" Unpublished paper, Nuffield College, Oxford,1999).

${ }^{44}$ William E. Connolly, Identity Difference: Democratic Negotiations of Political Paradox (Ithaca, NY: Cornell University Press, 1991).

${ }^{45}$ See, for example, Seyla Benhabib, "Communicative Ethics and Contemporary Controversies in Practical Philosophy," in The Communicative Ethics Controversy, eds. Seyla Benhabib and Fred Dallmayr (Cambridge, MA: MIT Press, 1990); James Bohman, "Public Reason and Cultural Pluralism: Political Liberalism and the Problem of Moral Conflict," Political Theory 23 (1995): 253-79; Dryzek, Discursive Democracy, 16-17; Carol Gould, Rethinking Democracy (Cambridge: Cambridge University Press, 1988), 18, 126-7; Gerry Mackie, "Models of Democratic Deliberation," paper presented at the Annual Meeting of the American Political Science Association, Chicago, 1995.

${ }^{46}$ Sunstein, "Deliberation, Democracy, Disagreement."

${ }^{47}$ For a qualitative approach, see Maarten Hajer, The Politics of Environmental Discourse: Ecological Modernization and the Policy Process (Oxford: Oxford University Press, 1995). For a quantitative method, see John S. Dryzek and Jeffrey Berejikian, "Reconstructive Democratic Theory," American Political Science Review 87 (1993): 48-60.

${ }^{48}$ Elizabeth Theiss-Morse, Amy Fried, John L. Sullivan, and Mary Dietz, "Mixing Methods: A Multi-Stage Strategy for Studying Patriotism and Citizen Participation," Political Analvsis 3 (1992): 89-122. 
${ }^{49}$ Hajer, The Politics of Environmental Discourse, 269.

${ }^{50}$ In standard individualistic accounts of democracy, legitimacy is granted to collective outcomes by people who disagree with them either as a result of instrumental calculation that they have a good chance of winning at some future point under the prevailing system of rules, or through recognition that procedures were transparent and fair. The latter principles can be applied in a deliberative context. As Cohen puts it, "Because the members of a democratic association regard deliberative procedures as the source of legitimacy, it is important to them that the terms of their association not merely be the results of their deliberation, but that it be manifest to them as such" [emphasis in original]. Cohen, "Deliberation and Democratic Legitimacy," 21.

${ }^{51}$ An additional reason why an individualistic ontology is inappropriate is that discourses are not like parties or clubs or groups, for they do not have members, and so are not reducible to a well-defined set of members. It is quite possible for any individual to have simultaneous leanings toward multiple, perhaps incompatible, discourses. Or, to put it another way, subjectivity can be multi-dimensional. See Jon Elster, ed., The Multiple Self (Cambridge: Cambridge University Press, 1986). For example, part of me may subscribe to a radical green critique of industrial society; another part of me may evaluate government according to how well it is promoting economic growth and a positive investment climate. Different (discursive) situations may invoke these different aspects of subjectivity, which can be latent or manifest at any given time, or indeed not exist until the situation is such as to invoke the aspect in question. 
${ }^{52}$ Jane Mansbridge, "Everyday Talk in the Deliberative System," in Deliberative Politics: Essays on Democracy and Disagreement, ed. Stephen Macedo (New York: Oxford University Press, 1999): 211-38.

${ }^{53}$ See, for example, John S. Dryzek, Democracy in Capitalist Times: Ideals, Limits, and Struggles (New York: Oxford University Press, 1996).

${ }^{54}$ David Schlosberg, Environmental Justice and the New Pluralism: The Challenge of Difference for Environmentalism (Oxford: Oxford University Press, 1999). See also Douglas Torgerson, The Promise of Green Politics: Environmentalism and the Public Sphere (Durham, NC: Duke University Press, 1999), 148-54.

${ }^{55}$ For an example from the Southwest Network for Environmental and Economic Justice in the USA, see Schlosberg, Environmental Justice, 128.

${ }^{56}$ Habermas, Between Facts and Norms, 307.

${ }^{57}$ Dryzek, Democracy in Capitalist Times, 64-70.

John S. Dryzek is Professor of Social and Political Theory in the Research School of Social Sciences, Australian National University. 